Section Editor

Robert C. Griggs, MD
Editors' Note: Commenting on the study on the capacity of patients with Parkinson disease (PD) to consent to research by Karlawish et al., Abe raises important questions and observations on cognitive research in PD. Kim and Kim and $\mathrm{Xu}$ et al. critique the Yang et al. study on reduced dosage of rituximab in neuromyelitis optica (NMO). The authors agree with some of their points but also discuss the unclear relationship between clinical effects in NMO and exact numbers of B-cell counts.

—Chafic Karam, MD, and Robert C. Griggs, MD

\section{COGNITIVE IMPAIRMENT AND PD PATIENTS' CAPACITY TO CONSENT TO RESEARCH}

Kazuo Abe, Osaka, Japan: As Drs. Marson and Hershey $^{1}$ stated in their accompanying editorial, Karlawish et al. ${ }^{2}$ provided a welcome and timely scientific contribution to the field of PD clinical research. Ability to consent is crucial in determining effective treatment and research decision making for patients with PD. ${ }^{3,4}$ Karlawish et al. investigated research consent capacity (RCC) in patients with PD by using the MacArthur Competence Assessment Tool for Clinical Research (McCAT-CR). The authors found that patients with PD with both borderline impaired and impaired cognition had impairments in RCC, whereas cognitively normal patients with PD did not.

However, the authors did not mention slowing of reaction time or cognitive processing, which are major indicators of cognitive dysfunction. In addition, was there enough time given for the authors' consent process during assessment of the McCAT-CR? Clinicians usually observe patients with PD hesitating or showing no reaction during assessment of cognitive function, yet these reactions do not reflect lack of comprehension. The authors' answers to these questions may be helpful in developing rational processes for research consent in patients with PD.

Author Response: Jason H. Karlawish, Philadelphia: We thank Dr. Abe for his thoughtful comments. People with PD-even those without obvious cognitive impairment-routinely experience psychomotor slowing, including delays in task completion and responses to questions. As a result, we avoided using these measures to determine level of cognitive
WriteClick: Editor's Choice

impairment or to screen cognition for comparison with capacity evaluations. Our evaluators were experts in the assessment and evaluation of PD and thus understood the importance of allowing ample time for responses.

Nevertheless, Dr. Abe raises an intriguing question that we cannot yet answer: How do not only the cognitive but also the motor and affective characteristics of the person being evaluated influence a capacity evaluator's judgment? There are insufficient data to answer this question, especially in PD. In Alzheimer disease, capacity experts have wondered how long information must be retained or how well "the big picture" must be grasped in order to find a person capable of research consent.

In PD, symptoms such as reduced verbal retrieval, blunted affect, and motor slowing may be associated with capacity judgments, but that analysis was beyond our scope. Our focus was on the association between global measures of cognitive performance and capacity evaluation in PD.

(C) 2014 American Academy of Neurology

1. Marson DC, Hershey LA. Decisional capacity in cognitively impaired patients with Parkinson disease. Neurology 2013; 81:1-2.

2. Karlawish J, Cary M, Moelter ST, et al. Cognitive impairment and PD patients' capacity to consent to research. Neurology 2013;81:801-807.

3. Determining Capacity to Consent. Dialogue. Available at: http:// www.cpso.on.ca/uploadedFiles/policies/policies/policyitems/ capacity_consent_july07dialogue.pdf. Accessed August 30, 2013.

4. Nicholson TR, Cutter W, Hotopf M. Assessing mental capacity: the Mental Capacity Act. BMJ 2008;336:322-325.

\section{RESPONSIVENESS TO REDUCED DOSAGE OF RITUXIMAB IN CHINESE PATIENTS WITH NEUROMYELITIS OPTICA}

Ho Jin Kim, Su-Hyun Kim, Goyang-si, Gyeonggi-do, Korea: Yang et al. ${ }^{1}$ reported on reduced-dose rituximab treatment in NMO. To demonstrate the efficacy of rituximab, it is critical to show the relationship between the clinical response and B-cell depletion. Low-dose rituximab requires greater vigilance than conventional dosages, and appropriate monitoring is essential. However, the irregular B-cell monitoring (sometimes greater than 15 weeks) in this study is 


\section{Neurology}

\section{Cognitive impairment and PD patients' capacity to consent to research}

Kazuo Abe and Jason H. Karlawish

Neurology 2014;82;546

DOI 10.1212/WNL.0000000000000074

This information is current as of February 10, 2014

\section{Updated Information \&} Services

References

Permissions \& Licensing

Reprints including high resolution figures, can be found at: http://n.neurology.org/content/82/6/546.1.full

This article cites 3 articles, 3 of which you can access for free at: http://n.neurology.org/content/82/6/546.1.full\#ref-list-1

Information about reproducing this article in parts (figures,tables) or in its entirety can be found online at:

http://www.neurology.org/about/about_the_journal\#permissions

Information about ordering reprints can be found online:

http://n.neurology.org/subscribers/advertise

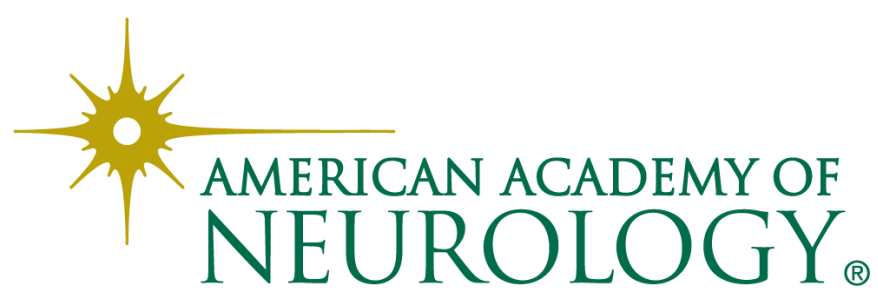

